\title{
Policy Problems in Financing Vocational and Technical Education: Implications for Technological Advancement
}

\author{
Cajethan U. Ugwuoke ${ }^{1^{*}}$ Blessing I. Onyebuchi ${ }^{1} \quad$ Chinyere R. Okwo ${ }^{1} \quad$ Godwin E. Eze $^{1}$ \\ Jane E. Agege ${ }^{2}$ Lilian U. Ekenta \\ 1.Department of Agricultural Education, University of Nigeria, Nsukka \\ 2.Ambrose Alli University, Ekpoma, Edo State, Nigeria
}

\begin{abstract}
This study was designed to investigate policy problems in financing vocational and technical education with implication on technological advancement. The study adopted a survey research design. The population of the study was 195 lecturers in Enugu State higher institutions. Two higher institutions were randomly selected and the entire 80 lecturers were included in the study. The instrument used for data collection was a structured questionnaire designed by the researchers. The questionnaire was validated by 3 experts, while the internal consistency of the questionnaire items was determined using Cronbach alpha method which yielded a reliability coefficient of 0.88 . The data collected were analysed using mean and standard deviation to answer the research questions while t-test statistic was used to test the null hypotheses at 0.05 level of significance. The study found out that Tertiary Education Tax Fund (TETFUND), students' tuition fee, research grants, the Federal and State Government budgetary allocation are the major sources of financing vocational and technical education. Absence of direct policy on vocational and technical education financing, non-inclusion of vocational and technical education experts in policymaking and absence of policy to checkmate indiscipline and corruption of the leaders were found to be the policy problems in financing vocational and technical education. The researchers recommend among others that policy formulations relating to vocational and technical education should be handled by VTE specialist but not just education experts.
\end{abstract}

Keyword: Policy, Policy problems, financing, vocational and technical education, technological advancement.

DOI: $10.7176 / J L P G / 91-11$

Publication date: November $30^{\text {th }} 2019$

\section{Introduction}

Vocational and Technical Education (VTE) has currently become the focus of the world economy. Okolocha (2012) stated that as advances in technology draw the world more closely together; vocational and technical preparedness becomes increasingly important. This led to the renewed interest of the world in vocational and technical education as a pillar for individual and national economic survival. According to Chairman on Press Conference cited in Wikipedia (2016), this renewed interest aimed at encouraging Nigerian youths to take to vocational and technical education which is the direction the whole world is going now. Vocational and technical education is an aspect of education process involving in addition to general education, the study of technologies and related science and the acquisition of practical skills, attitudes, understanding and knowledge relative to occupations in various sectors of economic and social life (Federal Republic of Nigeria, 2013). VTE is characterized with prosperous opportunities and high potentials through dynamic and technological advancement to create market for wide varieties of skills, job creation ability, employment and wealth generation capabilities, increase food production, and supply ability to stabilized deteriorating economy, and the general socio-economic and industrial growth of a nation. In this study, VTE is defined as education and training on technologies with technical knowledge, vocational skills and structural experiences acquired on-the-job or off-the-job necessary for agricultural, industrial, commercial and economic development of an individual towards national building. VTE programme is capital intensive due to its affiliation with a changing technological advancement. However, for the programme to achieve its objective in any economy, effective policy framework and implementation should be vehemently considered.

The policy is a proposed course of action which government intends to implement in respect of a given problem or situation confronting it (Ikechukwu and Chukwuemeka, 2013). According to Boaji, Gray and Campbell (2015), policies are designed to bring to life the perspective, realities and tools to improve education system in a changing society. Policy exists in all sectors of the economy including education. Education policy is the collection of laws and rules that govern the operation of an education system to achieve its objectives. Unfortunately, policy in Nigeria ends on paper with little visible achievement without area of core interest to improve the programme challenges. David (2017) stated that most of the policymakers for education in Nigeria do not specialize in the field to know the core areas of challenges toward building a viable policy objective for vocational and technical education. David stressed further that those policymakers in education may not specialize in vocational and technical education to determine the major areas of concern and interest for effective policy objectives in area of financing. As such, vocational and technical education suffers policy problems in 
financing the programme.

Financing of vocational and technical education is of increasing concern to governments as well as, in many countries to industries. Finance according to Amadi and Johnwest (2016), is a field that deals with the allocation of assets and liabilities over time under conditions of certainty and uncertainty. In the context of this study, financing simply means the process of providing funds for equipping vocational and technical education institutions with relevant technologically advanced tools and experts required in meeting the set objectives of the programme. In Nigeria, the Federal Ministry of Education, the Federal Ministry of Science and technology, the Federal Ministry of labour and productivity, and the Federal Ministry of finance are all agencies responsible for financing the development of vocational and technical education and related policies (UNESCO, 1996). Despite these, Ogbuanya and Okoye (2015) stated that Nigerian higher institutions lack the requisite tools to impart skills needed by the employers and this results to the shooting up of youth unemployment. Abie and Eya (2017) further pointed out that poor funding to ameliorate inadequate infrastructure and poor ICT facilities is among the basic challenges of vocational and technical education in Nigeria. Hence, the need to study the problems associated with policy in financing vocational and technical education.

\section{Statement of the Problem}

Financing is a crucial issue in vocational and technical education programme in any country, no matter at what stage of development. In Nigeria, several core governmental agencies are responsible for financing vocational and technical education and its related policies but none of the agencies enacted direct financing policy for vocational and technical education on the emerging technological advancement in Nigeria. As such, provision of fund meant to finance the programme is often diverted to unknown projects, thereby subjecting the present vocational and technical education programme in Nigeria to acute financing challenges. Towards proffering solution to improve this challenge, financing strategies through Education Tax Fund (ETF) and Tertiary Education Tax Fund (TETFUND) was adopted among the tertiary institutions as sources of financing the education programme in general. However, appropriate policies were still not implemented to sufficiently finance and equip vocational and technical education programme. Thus, leading to an increase in the rate of unemployment in Nigeria. This, therefore, necessitated the study on policy problems in financing VTE in Nigeria.

\section{Purpose of the Study}

The general purpose of this study was to investigate the policy problems in financing VTE in Nigeria. Specifically, the study sought to:

1. identify the sources of financing vocational and technical education

2. ascertain the policy problems in financing vocational and technical education

3. determine strategies for improving the financing of vocational and technical education through policy

\section{Methodology}

The study adopted a descriptive survey research design. The study was conducted in Enugu State, Nigeria. Population for the study consisted of 195 representing all the lecturers of government-owned higher institutions in Enugu state. The government-owned higher institutions in Enugu state are the University of Nigeria Nsukka, Enugu State University of Science and Technology, Institute of Management and Technology, Federal College of Education Eha-Amufu and Enugu State College of Education (Technical) Enugu. Simple random sampling technique was used to select two higher institutions: namely, Enugu State University of Science and Technology and Enugu State College of Education (Technical), Enugu. The entire 80 lecturers consisting of 43 VTE lecturers of Enugu State University of Science and Technology and 37 VTE lecturers of Enugu State College of Education (Technical) were included in the study.

The instrument used for data collection was structured questionnaire titled "Policy Problems in Financing Vocational and Technical Education Questionnaire (PPFVTEQ)" which was developed by the researchers from literature based on the three research questions formulated to guide the study. The questionnaire was validated by three experts from the Faculty of Vocational and Technical Education, Ebonyi State University Abakaliki, while the internal consistency of the questionnaire items was determined using Cronbach Alpha method which yielded a reliability coefficient of 0.88 .

The questionnaire was administered to the respondents by the researchers. Eighty copies of the questionnaire were administered and sixty copies were correctly filled and returned showing a return rate of $75 \%$.

The three research questions were answered using mean and standard deviation. The decision was taken using real limit of numbers based on grand mean. Any item with the mean value of 4.50 and above was regarded as strongly agree, 3.50-4.49 was interpreted as agree, 2 .50-3.49 as undecided, 1.50-2.49 as disagree and 0.501.49 as strongly disagree. Similarly, t-test statistic was used to test the null hypotheses at 0.05 level of significance. 


\section{Results}

Table 1: Mean and t-test Analysis of the Responses of Lecturers of Enugu State University of Science and Technology and Enugu State College of Education (Technical) on the Sources of Financing Vocational and Technical Education

\begin{tabular}{|c|c|c|c|c|c|c|c|}
\hline $\mathbf{S} / \mathbf{N}$ & Item Statement & Mean & SD & Rem & $\mathbf{t}$ & $\begin{array}{l}\text { p- } \\
\text { value }\end{array}$ & Dec \\
\hline 1 & Tuition fee & 4.8 & 0.34 & SA & 0.15 & 0.56 & NS \\
\hline 2 & Alumni association fund support & 4.6 & 0.63 & SA & 0.06 & 0.68 & NS \\
\hline 3 & Local government/host community fund support & 3.9 & 0.81 & A & 0.11 & 0.91 & NS \\
\hline 4 & $\begin{array}{l}\text { Company and non-governmental organizations support } \\
\text { fund }\end{array}$ & 3.7 & 0.79 & A & 0.08 & 0.76 & NS \\
\hline 5 & Endowment fund/donation & 3.6 & 0.78 & A & 0.08 & 0.21 & NS \\
\hline 6 & Federal and State Government budgetary allocation & 4.7 & 0.71 & SA & 0.14 & 0.18 & NS \\
\hline 7 & Tertiary Education Trust Fund (Tetfund) & 4.6 & 0.54 & SA & 0.22 & 0.33 & NS \\
\hline 8 & International aids & 4.5 & 0.48 & SA & 0.34 & 0.51 & NS \\
\hline 9 & Research grants & 4.4 & 0.91 & A & 0.19 & 0.25 & NS \\
\hline \multicolumn{2}{|r|}{ Total } & 4.31 & 0.56 & $\mathbf{A}$ & 0.15 & 0.49 & NS \\
\hline
\end{tabular}

The respondents strongly agree that tuition fee (4.8 \pm 0.63$)$, alumni support fund (4.6 \pm 0.63$)$, Federal and

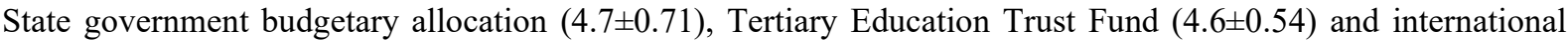
aids $(4.5 \pm 0.48)$ are the sources of finance for vocational and technical education (Table 1). Similarly, the respondents agree that vocational and technical education can be financed by the local government/host

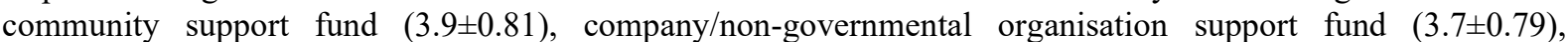
endowment funds/donation (3.6 \pm 0.78$)$ and research grant (4.4 \pm 0.91$)$. The probability values of all the items were greater than 0.05 (Table 1). This implied that there was no statistically significant difference $(\mathrm{p}>0.05=0.49,0.15)$ in the mean responses of the lecturers on the sources of finance for vocational and technical education

Table 2: Mean and t-test Analysis of the Responses of Lecturers of Enugu State University of Science and

Technology and Enugu State College of Education (Technical) on the Policy Problems in Financing Vocational and Technical Education

\begin{tabular}{|c|c|c|c|c|c|c|c|}
\hline $\mathbf{S} / \mathbf{N}$ & Item Statement & Mean & SD & Rem & $\mathbf{t}$ & $\begin{array}{l}\text { p- } \\
\text { value }\end{array}$ & Dec \\
\hline 10 & $\begin{array}{l}\text { Vocational technical education specialists not included in } \\
\text { vocational and technical education policies }\end{array}$ & 4.6 & 0.66 & SA & 0.14 & 0.09 & NS \\
\hline 11 & $\begin{array}{l}\text { Absence of direct policy on vocational and technical } \\
\text { education financing }\end{array}$ & 4.8 & 0.38 & SA & 0.26 & 0.14 & NS \\
\hline 12 & $\begin{array}{l}\text { Absence of vocational and technical education policy on } \\
\text { students/facilities carrying capacity }\end{array}$ & 3.6 & 0.24 & A & 0.08 & 0.27 & NS \\
\hline 13 & $\begin{array}{l}\text { Absence of policy to checkmate indiscipline and corruption } \\
\text { among the leaders }\end{array}$ & 4.4 & 0.81 & A & 0.18 & 0.91 & NS \\
\hline 14 & $\begin{array}{l}\text { Absent of policy and law against the diversion of fund } \\
\text { meant for vocational and technical education to other } \\
\text { sectors }\end{array}$ & 3.7 & 0.51 & A & 0.15 & 0.10 & NS \\
\hline \multirow[t]{2}{*}{15} & Absence of policy to support the creation of vocational and & 4.7 & 0.38 & SA & 0.18 & 0.29 & NS \\
\hline & Total & 4.3 & 0.50 & $\mathbf{A}$ & 0.67 & 0.30 & NS \\
\hline
\end{tabular}

The respondents strongly agree that the non-inclusion of VTE specialists in VTE policies $(4.6 \pm 0.66)$, no direct policy on VTE financing $(4.8 \pm 0.38)$ and no policy for the creation of VTE ministry $(4.7 \pm 0.38)$ are the policy problems in financing vocational and technical education (Table 2). The respondents equally agree that absence of VTE policy on students/facilities carrying capacity (3.6 \pm 0.24$)$, absence of policy to checkmate indiscipline and corruption of the leaders $(4.4 \pm 0.18)$ and absent of policy and law against the diversion of fund meant for vocational and technical education (3.7 \pm 0.51$)$ are the policy problems affecting financing of vocational and technical education. Furthermore, the p-values of the items were greater than 0.05 (Table 2). This signified that significant difference did not exist $(p>0.05=0.30,0.67))$ in the responses of the respondents on the policy problems affecting the financing of vocational and technical education. 
Table 3: Mean and t-test Analysis of the Responses of the Respondents on the Strategies of Improving the Financing of Vocational and Technical Education Through Policy

\begin{tabular}{clcccccc}
\hline S/N & Item Statement & Mean & SD & Rem & t & $\begin{array}{c}\text { p- } \\
\text { value }\end{array}$ & Dec \\
\hline 16 & $\begin{array}{l}\text { Inclusion of vocational and technical education specialists } \\
\text { in vocational and technical education policy formulations }\end{array}$ & 4.8 & 0.39 & SA & 0.03 & 0.12 & NS \\
17 & $\begin{array}{l}\text { Policy on direct vocational and technical education } \\
\text { financing }\end{array}$ & 4.2 & 0.66 & $\mathrm{~A}$ & 0.08 & 0.10 & NS \\
18 & $\begin{array}{l}\text { Provision of VTE policy on students/facilities carrying } \\
\text { capacity }\end{array}$ & 4.7 & 0.73 & SA & 0.11 & 0.17 & NS \\
19 & $\begin{array}{l}\text { Involvement of transparent and accountable vocational and } \\
\text { technical education system }\end{array}$ & 4.6 & 0.57 & SA & 0.09 & 0.19 & NS \\
20 & $\begin{array}{l}\text { Policy on the non-interception of government to foreign } \\
\text { aids meant for vocational and technical education }\end{array}$ & 4.4 & 0.49 & A & 0.14 & 0.23 & NS \\
21 & $\begin{array}{l}\text { Policy on the creation of the ministry of vocational and } \\
\text { technical education Total }\end{array}$ & 4.5 & 0.58 & SA & 0.18 & 0.20 & NS \\
\hline
\end{tabular}

The respondents strongly agree that inclusion of vocational and technical education specialist in vocational and technical education policy formulations (4.8 \pm 0.39$)$, provision of VTE policy on students/facilities carrying capacity (4.7 \pm 0.73$)$, transparent and accountable vocational and technical education leaders (4.6 \pm 0.57$)$ and policy on the creation of ministry of VTE $(4.5 \pm 0.58)$ are the strategies of improving the financing of vocational and technical education (Table 3). Similarly, the respondents agree that policy on direct vocational and technical education financing $(4.2 \pm 0.66)$ and policy on non-interception of the government to foreign aids meant for vocational education (4.4 \pm 0.49$)$ are the strategies of improving the financing of vocational and technical education. Furthermore, Table 3 shows that the p-values of the items were greater than 0.05 , which implies that no statistically significant difference $(p>0.05=0.17,0.11)$ existed in the mean responses of the lecturers.

\section{Discussion of the Findings}

It was found out that tuition fee $(4.8 \pm 0.63)$, alumni support fund $(4.6 \pm 0.63)$, Federal and State government budgetary allocation $(4.7 \pm 0.71)$, Tertiary Education Trust Fund (4.6 \pm 0.54$)$, international aids $(4.5 \pm 0.48)$, local

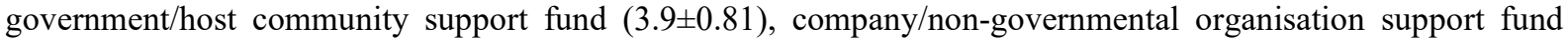
(3.7 \pm 0.79$)$, endowment funds/donation (3.6 \pm 0.78$)$ and research grant $(4.4 \pm 0.91)$ are some of the sources of financing vocational and technical education. In a similar study, it was found out that funding can be improved for effective animal husbandry delivery through grants from the government, school fees from the students, alumni support and donation from the philanthropists (Omeje et al., 2018). Innovative financing such as academic facility user fees, solidarity levy and Value-Added Tax (VAT) proceeds generated by institutions offering vocational and technical education (VTE) should make VTE programme effective and efficient (Mokwena, 2015 cited in Ezema et al., 2017). The vocational and technical education programme is expensive in nature and therefore, finance must be derived from the budgetary allocation of the government, students' school fees, and donations for the procurement of equipment and facilities, and maintenance of existing ones as well as training of personnel (Amadi and JohnWest, 2016).

It was equally found out that the non-inclusion of VTE specialists in VTE policies $(4.6 \pm 0.66)$, no direct policy on VTE financing (4.8 \pm 0.38$)$ and no policy for the creation of VTE ministry (4.7 \pm 0.38$)$, absence of VTE policy on students/facilities carrying capacity (3.6 \pm 0.24$)$, absence of policy to checkmate indiscipline and corruption of the leaders $(4.4 \pm 0.18)$ and absent of policy and law against the diversion of fund meant for vocational and technical education $(3.7 \pm 0.51)$ were the policy problems affecting the financing of vocational and technical education. Furthermore, a significant difference did not exist $(p>0.05=0.30,0.67)$ ) in the responses of the respondents on the policy problems affecting the financing of vocational and technical education. Okolocha (2012) identified policy as the major challenges confronting the financing of vocational and technical education emphasizing that poor policy implementation has been the major bane to vocational and technical education development. The distortion in the quality of vocational and technical education can be attributed to the ineffective policy implementation engendered primarily by lack of political will, lack of continuity of programme and corruption among the implementers (Okoroma, 2006). This was emphasized by Viennet and Pont (2017) that the realization of quality vocational and technical education is affected by the insufficient focus on policy implementation which leads to the people losing confidence and patience with policymakers and implementers. Deviation in policy implementation can be linked to the non-involvement of specialists during policy formulation.

It was revealed that the inclusion of vocational and technical education specialist in vocational and technical education policy formulations (4.8 \pm 0.39$)$, provision of VTE policy on students/facilities carrying capacity 
$(4.7 \pm 0.73)$, transparent and accountable vocational and technical education leaders $(4.6 \pm 0.57)$, policy on direct vocational and technical education financing (4.2 \pm 0.66$)$, policy on non-interception of the government to foreign aids meant for vocational education $(4.4 \pm 0.49)$ and policy on the creation of VTE ministry are the strategies of improving the financing of vocational and technical education through policy. It was equally found out that there was no statistically significant difference $(p>0.05=0.17,0.11)$ in the mean responses of the respondents on the strategies of improving the financing of vocational and technical education through policy. It was found in a related study that task allocation and accountability mechanism, objective focus, systematic data monitoring and evaluation are the strategies policy implementers should adopt to ensure transparent and accountable financial prudent vocational and technical education (Viennet and Pont, 2017). Financial education policy was found out to be part of government literacy related to money management, planning and protection which involve planning, saving, prevention and protection against fraud and financial abuse (OECD, 2015). Financial education is used in many countries to control the fraudulent waste of public fund meant for the development of vocational and technical education.

\section{Conclusions}

Implementation of formidable and quality vocational and technical education needs huge financial involvements which can be acquired through government budgetary allocation, students' tuition fees, alumni and donations. Vocational and technical education is not given the proper place in Nigeria by involving specialists in VTE policy formulations, non-direct policy on VTE financing and non-implementation of policies to checkmate the indiscipline and corruption of the leaders of VTE. Improving the financing of vocational and technical education through proper policies is imperative so as to involve the specialists in policy formulation which will translate into proper implementation. Policy on direct allocation of finance to vocational and technical education is necessary to avoid financial competition with general education.

\section{Recommendations}

Based on the findings of the study, the following recommendations were made:

1. More innovative sources of financing vocational and technical education should be investigated and applied in addition to the existing ones.

2. Policy formulation relating to vocational and technical education must be handled by VTE specialists but not general education experts. This will make it possible for the core area of concern in VTE like provision of modern facilities/equipment; training and retraining of experts and institutions/industrial relationship to be taken seriously.

3. Provision of policy against the diversion of funds meant for VTE to other sectors should be made and strictly enforced. Such that any management or authority in the position found guilty shall be prosecuted.

\section{References}

Abie, E.O. \& Eya, S.O. (2017). Technical Vocational Education and Training (TVET): An imperative for postoil boom economic growth. Journal of Association of Vocational and Technical Education of Nigeria (JAVTEN), 22(1), 35-41.

Amadi, N.S. \& JohnWest, E.K. (2016). Current trends in financing Vocational Education in Nigeria. International Journal of education and evaluation, 2(2) 12-18. Retrieved from https://www.iiardpub.org

Bolaji, S.D., Gray, J.R. \& Campbell, E.G. (2015). Why do policies fail in Nigeria? Journal of Education and social policy, 2(2), 57-66. Retrieved from https://www.researchgate.net

David, A. (2017). Financing Vocational Education: Concepts, Examples and Tendencies. International Institute for Educational Planning (IIEP). Training discussion paper. No.71 Geneva

Ezema, C.J., Ugwoke, O.E. \& Edeh, I.N. (2017). Innovative financing strategies for effective Technical and Vocational Education and Training (TVET) delivery for oil boom economy. Journal of Association of Vocational and Technical Educators of Nigeria (JAVTEN), 22(2), 22-27.

The Federal Republic of Nigeria. (2013). National Policy on Education (6 $6^{\text {th }}$ ed). Lagos: NERDC press

Ikechukwu, U.I. \& Chukwuemeka, E.E.O. (2013). The obstacles to effective policy implementation by the public bureaucratic in developing nations: The case of Nigeria. Kuwait Chapter of Arabian Journal of Business and Management Review, 2(7), 59-68

Ogbanya, T.C. \& Okoye, P.I. (2015). Repositioning Technology and Vocational Education and Training (TVET) for Poverty Reduction in Nigeria. International Journal of Vocational and Technical Education Research. $1(2), 10-21$

Okolocha, C.C. (2012). Vocational and technical education in Nigeria: Challenges and way forward. Business Management Dynamics, 2(6), 01-08

Okoroma, N.S. (2006). Educational policies and problems of implementation in Nigeria. Australian Journal of 
Adult Learning, 46(2,) 243-263

Omeje, B.A., Ugwuoke, C.U. \& Eze G.E. (2018). Improving Funding in Education for Effective Animal Husbandry Delivery in Nsukka Education Zone of Enugu State. Journal of Centre for Technical Vocational Education, Training and Research, 3(1), 69-76

Organisation for Economic Co-operation and Development (OECD). (2015). National Strategies for Financial Education OECD/INFE Policy Handbook. Retrieved from http://www.oecd.org/finance/NationalStrategies-Financial-Education-Policy-Handbook.pdf

UNESCO-UNEVOC. (1996). Financing Technical and Vocational Education: Modalities and Experience. VOCED Plus NCVER's International tertiary Education research database. Africa; Asia 62. Retrieved on 28/06/2019 from https://www.unevoc.net/fileadmin/user-upload/pubs/iug006e.pdf

Viennet, R. \& Pont, B. (2017). Education Policy Implementation: A Literature Review and Proposed Framework. Directorate for Education and Skills. Organisation for Economic Co-operation and Development

Wikipedia (2016). Financing - Wikipedia, the free encyclopaedia. https://en.wikipedia.org/wiki/Finance 